\title{
The effect of prey quality and ice conditions on the nutritional status of Baltic gray seals of different age groups
}

\author{
Kaarina Kauhala $^{1} \cdot$ Britt-Marie Bäcklin $^{2} \cdot$ Jari Raitaniemi $^{1} \cdot$ Karin C. Harding $^{3}$
}

Received: 19 May 2017 / Accepted: 13 July 2017

(C) Mammal Research Institute, Polish Academy of Sciences, Białowieża, Poland 2017

\begin{abstract}
We analyzed a long-term data set of the body condition of Baltic gray seals (Halichoerus grypus) over time and investigated how average subcutaneous blubber thickness of different age groups of seals corresponds to environmental factors. Blubber thickness of pups declined until 2010. The decreasing weight of 5-6-year-old herring (Clupea harengus), the main prey fish for Baltic gray seals, explained well the decline. In the Gulf of Finland, the blubber thickness of pups declined also in recent years (2011-2015) with declining number of days with permanent ice cover. In other regions, the blubber thickness of pups increased during recent years with increasing weight of herring. The blubber thickness of subadults in Baltic Proper and that of hunted adult females in the Bothnian Bay also increased during recent years, and the weight of age $6+$ or 7 -year-old herring best explained the increase. The blubber thickness of all age groups of seals was thinnest in the Bothnian Bay where also herring weight was lowest. There was a negative correlation between blubber thickness of seals and herring catch size (an index of herring abundance) suggesting that herring quality, not the quantity, is important for the nutritional status of Baltic gray seals. Nutritional status of gray seals may thus reveal changes in
\end{abstract}

Communicated by: Cino Pertoldi

Kaarina Kauhala

kaarina.kauhala@luke.fi

1 Luonnonvarakeskus Luke (Natural Resources Institute Finland), Itäinen Pitkäkatu 3 A, 20520 Turku, Finland

2 Department of Environmental Research and Monitoring, Swedish Museum of Natural History, P.O. Box 50007, 104 05 Stockholm, Sweden

3 Department of Biological and Environment Sciences, University of Gothenburg, P. O. Box 461, 40530 Gothenburg, Sweden the marine food web which affect herring quality. Marine food web, in turn, may be affected, e.g., by climate change. The warming climate also has an impact on ice cover and thus body condition of seal pups.

Keywords Baltic food web $\cdot$ Blubber thickness $\cdot$ Climate change $\cdot$ Halichoerus grypus $\cdot$ Herring

\section{Introduction}

Marine mammals in strongly seasonal environments rely on their subcutaneous blubber layer for thermal insulation during the cold season, but also for energy storage during periods with little and inactive prey. Average thickness of the blubber layer in a population varies between years with environmental conditions and can be used as an index of nutritional status of seals. Blubber layer and weight of pups of the year are closely correlated to their subsequent first year survival (Hall et al. 2001; Harding et al. 2005) but also have delayed effects influencing age at sexual maturity and size at first parturition of female seals (Boyd et al. 1999; Bowen et al. 2015). Blubber thickness may also affect reproductive rate of mature females through implantation of embryos and fetal mortality (e.g., Boyd 1984). Variation of blubber thickness of seals is thus important for the growth rate of seal populations because it affects both mortality and reproductive rates.

Blubber thickness of seals is also adopted as an indicator of the environmental status of the Baltic Sea by international environmental protection authorities such as HELCOM (Harding et al. 2015). Primary environmental factors, which might affect blubber thickness, are the quantity and quality of food resources, e.g., a decline in the nutritional status of seals may indicate a change in the marine food web through the abundance or quality of prey species (Kjellqvist et al. 1995). 
Also, ice conditions during the breeding season may affect the nutritional status of gray seal pups, since gray seal females forced to breed on land during warm winters produce lighter pups at weaning compared to seals which normally breed on ice (Jüssi et al. 2008). In addition, parasites and diseases, as well as environmental contaminants, may have an effect on the nutritional status of marine mammals (Kuiken et al. 1994).

The main aims of the present study were to examine whether there is temporal or spatial variation in blubber thickness of Baltic gray seals of different age groups and to investigate whether variation in blubber thickness is connected to environmental factors. Environmental factors tested were the quality and quantity of the main food resource of the seals, i.e., the Baltic herring (Clupea harengus), and ice conditions in late winter. We paid special attention to pups, which are usually the first to suffer when environmental conditions become unfavorable (e.g., Lonergan et al. 2011), and adult females, because nutritional status is likely to affect their reproductive rate (Boyd 1984; Bowen et al. 2006).

\section{Material and methods}

\section{Seal tissue samples}

Samples from dead gray seals are routinely collected and analyzed at Natural Resources Institute Finland (Luke) and the Museum of Natural History in Sweden (SMNH) for environmental monitoring. We delimit the different sea regions as recommended by the International Council for the Exploration of the Sea (ICES; Fig. 1). Samples included in this study originated from Baltic Proper to the Bothnian Bay, i.e., ICES subdivisions (SD) 27 and 29-32 and were collected from 2002 to 2015. Samples originate from seals by-caught in fishing gears and those killed by hunting (Table 1). Hunting of seals is regulated through national authorities, and licenses to kill seals can be given to fishermen to protect fishing gear (Sweden) or as a regular annual hunt (Finland). Hunting season is from 16 April to 31 December (except in Åland to 31 January). No seals are killed for the purpose of monitoring or scientific research. In the present study, we did not include data from stranded seals because their blubber layer is often thin due to, e.g., different diseases and does not reflect the status of the environment in terms of food resources or ice conditions.

All samples collected included at least the lower jaw and genital organs. Also, standard measurements of body length (from the tip of the nose to the tip of the tail), weight (when possible), and blubber thickness were registered. Seal species was confirmed from the lower jaw, and age was determined from the annual incremental lines in the cementum of lower canine teeth (Mansfield 1991). Sex and reproductive status of females were verified from genital organs. Seals were

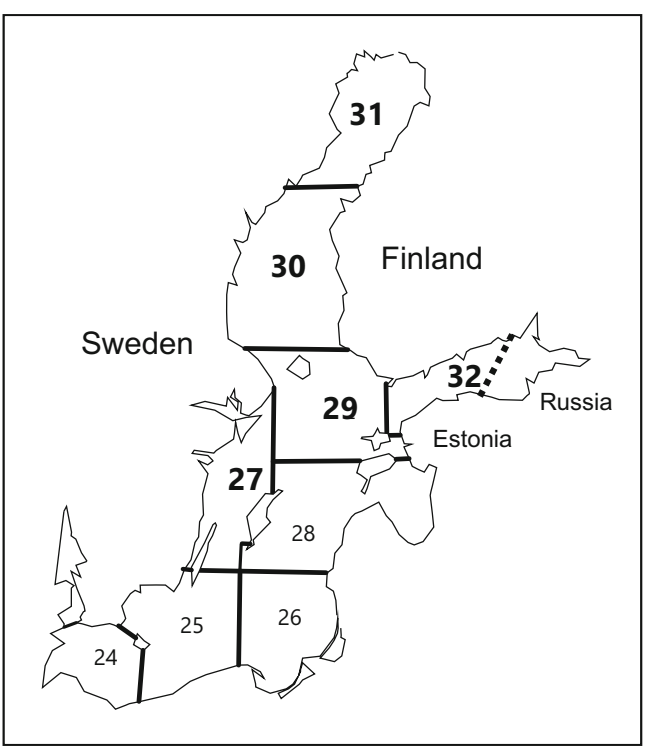

Fig. 1 The study area in the Baltic Sea covered ICES SD 27 and 29-32, excluding Estonian and Russian sea areas. ICES SD 27 = Baltic proper (BP), 29 = Archipelago Sea and Åland (hereafter Archipelago Sea, AS), $30=$ the Botnian Sea and the Northern Quark (hereafter the Bothnian Sea, BS), $31=$ the Bothnian Bay (BB) and $32=$ the Gulf of Finland (GF)

classified into three age groups: pups or juveniles, hereafter pups (less than 1 year old), sub-adults (1-3 years old), and adults (more than 3 years old) according to the practice used by HELCOM (Harding et al. 2015). Blubber thickness was measured in the field by Finnish and Swedish hunters and Finnish fishermen from the posterior end of the sternum, from skin to muscle to the nearest millimeter $(n=1529)$. In Sweden, the blubber layer of by-caught seals was measured in the laboratory by researches $(n=615)$. Hunters and fishermen were given strict orders how to measure the blubber thickness so that they did it in the same way as researchers. An earlier study (Bäcklin et al. 2011) indeed showed no significant difference between the values obtained by hunters or the personnel in the laboratory. Information on when and where the seal was shot or by-caught in fishing gear was also provided.

\section{Environmental data}

The number of days with permanent ice cover during the main breeding season of gray seals (from mid-February to midMarch) was obtained from the Finnish Meteorological Institute. We used here the data of ice cover from the western part of the Gulf of Finland, Archipelago Sea and Åland and the southern part of the Bothnian Sea where gray seals usually give birth. We excluded few places in the inner archipelago which have ice cover each year and where gray seals do not usually occur during the breeding season.

We used the average size of the commercial harvest (catch size) and the mean body weight of Baltic herring for age groups 5-6-year-old and age 6+ (6 years old and older) as 
Table 1 Number of gray seals of which samples were collected from the Finnish and Swedish sea regions in 2002-2015

\begin{tabular}{|c|c|c|c|c|c|c|c|}
\hline \multirow[t]{2}{*}{ Region } & \multicolumn{2}{|c|}{ Pups $(n=579)$} & \multicolumn{2}{|c|}{ Sub-adults $(n=465)$} & \multicolumn{2}{|c|}{ Adults $(n=1100)$} & \multirow[t]{2}{*}{ Total } \\
\hline & Hunted & By-caught & Hunted & By-caught & Hunted & By-caught & \\
\hline $\mathrm{BP}$ & 58 & 183 & 65 & 136 & 117 & 64 & 623 \\
\hline GF & 79 & 11 & 23 & 4 & 27 & 20 & 164 \\
\hline AS & 17 & 2 & 19 & 3 & 58 & 8 & 107 \\
\hline BS & 83 & 66 & 79 & 37 & 317 & 78 & 660 \\
\hline $\mathrm{BB}$ & 54 & 26 & 90 & 9 & 400 & 11 & 590 \\
\hline Total & 291 & 288 & 276 & 189 & 919 & 181 & 2144 \\
\hline
\end{tabular}

$B P$ Baltic Proper, $G F$ the Gulf of Finland, $A S$ Achipelago Sea, $B S$ the Botnian Sea, $B B$ the Bothnian Bay Pups: $<1$ year old, sub-adults: $1-3$ years old, adults: $>3$ years old indicators of the quantity vs quality of food resources, because herring is an important prey for gray seals in the Baltic Sea (Lundström et al. 2007, 2010). Catch size was used as an index of herring abundance, as they were positively related $\left(r^{2}>0.7\right)$ in both the Bothnian Sea and Central Baltic Sea during the study period (2003-2016). We excluded herring data of younger age groups, because gray seals mainly prey on large herring (Gårdmark et al. 2012). In the brackish water conditions of the Baltic Sea, herring is small sized and has essentially lower fat content compared to Atlantic herring (e.g., Keinänen et al. 2012; Slotte 1999; Vuorinen et al. 2002). The herring data from different sea regions was obtained from ICES (2016).

\section{Statistical tests}

Average blubber thickness of the total data and that of different age groups of seals was tested against several parameters: year, month, region, sex, age group (with relation to total data), and cause of death (hunted vs by-caught) by using a general linear model (GLM, software Systat 13). We used the stepwise backward procedure excluding the non-significant independent variables one at a time, the one with the highest $p$ value first. Only variables which significantly increased the $r^{2}$ values were included in the models. The level of significance was set to 0.05. However, we also took into account the AICC values in cases when there was a variable with $p$ value between 0.10 and 0.05 and chose the final model according to the lowest AICC value. In the results, means with standard errors $( \pm \mathrm{SE})$ of model predicted values of blubber thickness are given with all significant independent variables as covariates. When significant annual variation was found in blubber thickness, we examined the figures to find out possible time periods of upward or downward trends and tested the occurrence of the trend with regression analysis. We tested the normality of residuals with Kolmogorov-
Smirnov test. When residuals were not normally distributed, we performed Kruskal-Wallis analysis of variance in addition to GLM. The occurrence of autocorrelation was tested with Durbin-Watson test (Durbin and Watson 1951). In all cases, the value for the first-order autocorrelation was low $(<0.2)$, and therefore, we did not take autocorrelation into account.

The possible effects of environmental factors (ice conditions, weight, and catch size of herring) on the blubber thickness of seals were studied with regression or correlation analyses. When testing the possible effect of herring weight on blubber thickness, we first tested the correlations between each age group of herring against the blubber thickness of each seal group. Because the strongest correlations between herring weight and the blubber thickness were obtained when using either 5-6-year old herring or age $6+$ herring, we used these two groups of herring in the final regression analyses. The only exception was the blubber thickness of adult females: 7-year-old herring gave the most significant result.

\section{Results}

\section{Total data}

The model (GLM) indicated that all independent variables significantly affected the blubber thickness of gray seals (Table 2). Kruskal-Wallis analysis gave similar results. Thus, when examining temporal variation in blubber thickness, all independent variables were included as covariates. Blubber thickness of the pooled data for all seals decreased until 2010 (slope $=-0.44, F=7.3$, $p=0.007, n=1117$ ), but fluctuated thereafter (Fig. $2 a)$. The mean weight of 5-6-year-old herring best explained the decline before 2010 (Fig. 2b), but also age $6+$ herring explained well the decline in blubber 
Table 2 Results of GLM and Kruskal-Wallis analysis of variance for total gray seal data in 2002-2015 $(n=2144)$

\begin{tabular}{llllllll}
\hline Independent variables & \multicolumn{2}{l}{ GLM } & & & \multicolumn{2}{l}{ Kruskal-Wallis } \\
\cline { 2 - 3 } \cline { 7 - 8 } & $F$ & $d f$ & $P$ & & $K-W$ & $p$ \\
\hline Year & 2.9 & 13 & $<0.001$ & & 35.3 & 0.001 \\
Month & 38.7 & 8 & $<0.001$ & & 187.6 & $<0.001$ \\
Sex & 22.4 & 1 & $<0.001$ & 9.9 & 0.002 \\
Age group & 96.3 & 2 & $<0.001$ & 336.5 & $<0.001$ \\
Sea region & 14.7 & 4 & $<0.001$ & 95.9 & $<0.001$ \\
Cause of death & 308.3 & 1 & $<0.001$ & 371.2 & $<0.001$ \\
Multiple $R$ & 0.61 & & & & \\
Squared multiple $R$ & 0.37 & & & & \\
\hline
\end{tabular}

The effects of all independent variables on the blubber thickness of gray seals were tested in the same analysis to get a single model (GLM). F, $d f$, and $p$ for each independent variable, and multiple $R$ and squared multiple $R$ of the model are given. Cause of death: hunted vs by-caught. Age groups: pups: $<1$ year old, sub-adults: $1-3$ years old, adults: $>3$ years old. For sea regions, see Fig. 1. K-W = Kruskal-Wallis test statistic

thickness (Appendix Table 6). There was, however, negative correlations between herring catch size (an index of herring abundance) and the blubber thickness of seals (age 6+ herring: $r=-0.86, p=0.006$; Appendix Table 7) and between herring weight and catch size before 2010 ( $r=-0.93, p=0.001)$. Blubber thickness was lowest in the Bothnian Bay (mean for BB: $37.7 \mathrm{~mm} \pm 0.60, n=590$, for other areas: $42.2 \mathrm{~mm} \pm 0.41, n=1554$, ANOVA: $F=56.2$, $p<0.001$ ). The average weight of herring (age 5+)
Table 3 Blubber thickness of hunted and by-caught male and female gray seals of different age groups collected in 2002-2015

\begin{tabular}{lll}
\hline Age group & Males & Females \\
\hline $\begin{array}{l}\text { Hunted seals: } \\
\quad \text { Total }\end{array}$ & $40.8 \pm 0.58(725)$ & $42.9 \pm 0.62(761)$ \\
$\quad$ Pups & $33.6 \pm 0.86(159)^{\mathrm{a}}$ & $34.5 \pm 0.90(132)^{\mathrm{a}}$ \\
Sub-adults & $35.7 \pm 0.97(134)$ & $37.9 \pm 1.04(142)$ \\
Adults & $46.0 \pm 0.77(432)$ & $48.9 \pm 0.81(487)$ \\
By-caught seals: & & \\
$\quad$ Total & $31.8 \pm 0.74(421)$ & $34.7 \pm 0.82(237)$ \\
Pups & $24.8 \pm 0.62(152)^{\mathrm{a}}$ & $26.0 \pm 0.66(136)^{\mathrm{a}}$ \\
Sub-adults & $32.4 \pm 1.38(121)$ & $35.6 \pm 1.57(68)$ \\
Adults & $33.6 \pm 1.42(148)$ & $40.9 \pm 1.99(33)$ \\
\hline
\end{tabular}

Means \pm SE $(n)$ of model predicted values from GLM analyses are given (see Tables 2, 4, and 5). Pups: <1 year old, sub-adults: 1-3 years old, adults: $>3$ years old

${ }^{\text {a }}$ Original values because sex was not included in the model

was also lowest $(35.2 \mathrm{~g})$ in the Bothnian Bay (other areas: $43.2 \mathrm{~g}$ ). Blubber thickness declined from April to July and increased in the course of autumn (Fig. $2 c)$. Pups $(n=579)$ had the thinnest and adults $(n=1100)$ the thickest blubber layer, females $(n=998)$ had thicker blubber layer than males $(n=1146)$, and hunted seals $(n=1486)$ thicker than by-caught seals $(n=658$; Table 3$)$.

Because blubber thickness differed between age groups, which may be biologically important, we
Fig. 2 Blubber thickness of the pooled data of gray seals (means $\pm \mathrm{SE}$ and sample sizes of model predicted values with all significant independent variables as covariates): a variation between years, $\mathbf{b}$ blubber thickness of seals in 2003-2010 as a function of average weight of 5-6-year-old herring, and c variation between months. $B P$ Baltic proper, $G F$ the Gulf of Finland, $A S$ Archipelago Sea, $B S$ the Bothnian Sea, $B B$ the Bothnian Bay
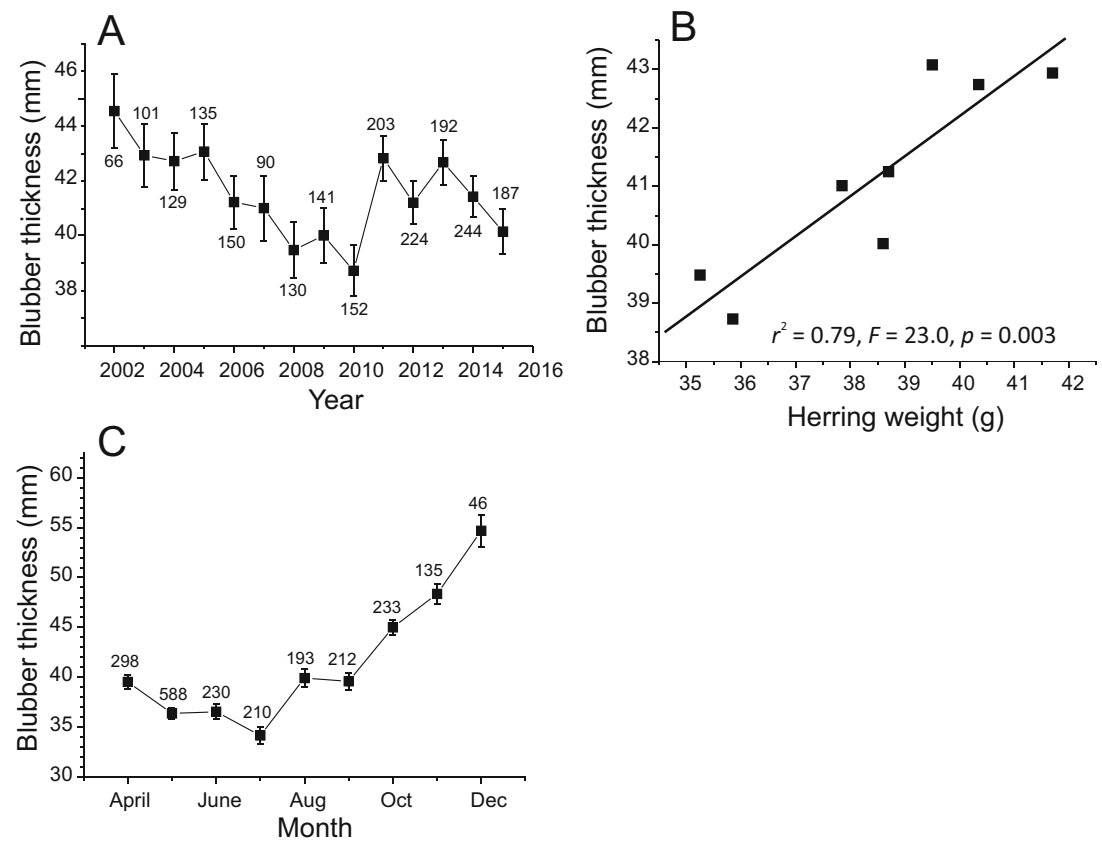
Table 4 Results of GLM for gray seal pups collected in 2002-2016 (12 pups were added from 2016)

\begin{tabular}{|c|c|c|c|c|c|c|c|c|c|}
\hline \multirow[t]{2}{*}{ Independent variable } & \multicolumn{3}{|c|}{ All regions $(n=591)$} & \multicolumn{3}{|c|}{ Baltic Proper (243) } & \multicolumn{3}{|c|}{ Bothnian Sea (154) } \\
\hline & $F$ & $d f$ & $p$ & $F$ & $d f$ & $P$ & $F$ & $d f$ & $p$ \\
\hline \multicolumn{10}{|l|}{ Total data of pups: } \\
\hline Year & 2.6 & 14 & 0.001 & 2.5 & 14 & 0.002 & 2.3 & 14 & 0.007 \\
\hline Month & - & - & - & - & - & - & 3.5 & 7 & 0.002 \\
\hline Sea region & 9.9 & 4 & $<0.001$ & - & - & - & - & - & - \\
\hline Cause of death & 134.7 & 1 & $<0.001$ & 121.0 & 1 & $<0.001$ & 37.0 & 1 & $<0.001$ \\
\hline Multiple $R$ & 0.52 & & & 0.64 & & & 0.69 & & \\
\hline Squared multiple $R$ & 0.27 & & & 0.41 & & & 0.47 & & \\
\hline \multicolumn{10}{|l|}{ Hunted pups (301): } \\
\hline Year & 4.0 & 14 & $<0.001$ & & & & & & \\
\hline Sea region & 14.9 & 4 & $<0.001$ & & & & & & \\
\hline Multiple $R$ & 0.51 & & & & & & & & \\
\hline Squared multiple $R$ & 0.26 & & & & & & & & \\
\hline \multicolumn{10}{|l|}{ By-caught pups (290): } \\
\hline Year & 2.5 & 14 & 0.003 & & & & & & \\
\hline Sea region & 2.9 & 4 & 0.022 & & & & & & \\
\hline Multiple $R$ & 0.39 & & & & & & & & \\
\hline Squared multiple $R$ & 0.15 & & & & & & & & \\
\hline
\end{tabular}

The effects of all independent variables on the blubber thickness of gray seals were tested in the same analysis to get a single model (GLM). F, $d f$, and $p$ for each independent variable, and multiple $R$ and squared multiple $R$ of the model are given. Independent variables tested were as follows: year, month, sea region, sex, and cause of death (hunted vs by-caught). For sea regions, see Fig. 1

recalculated the analyses separately for different age groups to get a more detailed picture of the spatial and temporal variation in blubber thickness.

\section{Pups}

Year, sampling region, and the cause of death (hunted vs bycaught) were significant when their impact on the blubber thickness of the total data of pups ( $n=591)$ was tested, whereas month and sex were not and were thus excluded from the model (Table 4).

Blubber thickness of pups declined until 2010 (slope $=-1.16, F=19.6, p<0.001, n=247$; Fig. $3 a)$ but fluctuated thereafter. The weight of 5-6-yearold herring best explained the decline $\left(r^{2}=0.65\right.$, $F=11.0, d f=1,6, p=0.016$; Appendix Table 6). Blubber thickness also declined from south (BP) to north (BB; Fig. 3b). By-caught pups were leaner than hunted pups (Table 3), but the trends over time were similar: blubber thickness of hunted pups declined from $37.2 \mathrm{~mm}( \pm 3.56)$ in 2002 to $24.6 \mathrm{~mm}( \pm 2.48)$ in 2010 (slope $=-1.47, F=11.77, p<0.001, n=86$ ), and that of by-caught pups declined from $29.4 \mathrm{~mm}( \pm 2.57)$ in 2003 to $20.2 \mathrm{~mm}( \pm 1.94)$ in 2010 (slope $=-0.98$, $F=15.5, p<0.001, n=156)$.

\section{Pup blubber thickness in the Gulf of Finland (effect of ice cover)}

To investigate spatial variation in blubber thickness of pups, we tested the temporal trends in blubber thickness separately for different areas (Table 4). There was a significant declining trend in the Gulf of Finland from 2011 to 2015 (Fig. 3c). The test was done for hunted pups because there were only 11 bycaught pups. Only the independent variable 'year' was included in the model (slope $=-3.1, F=18.9, p<0.001, n=81$ ), and a positive relationship between the blubber thickness of pups and the number of days with permanent ice cover was found $\left(r^{2}=0.85, F=16.8, d f=1,3, p=0.026\right)$. No significant correlation between herring weight and blubber thickness was found in the data set from GF for the same time period.

\section{Pup blubber thickness in the other regions (effect of herring weight)}

In the total data of pups, excluding the Gulf of Finland, there was a significant increasing trend from $27.3 \mathrm{~mm}( \pm 1.74)$ in 2010 to $35.4 \mathrm{~mm}( \pm 2.07)$ in 2016 (slope $=1.18, F=13.6$, $p<0.001, n=306$ ). The weight of 5-6-year-old herring best explained the increase $\left(r^{2}=0.78, F=14.0, d f=1,4, p=0.020\right.$, Appendix Table 6). 

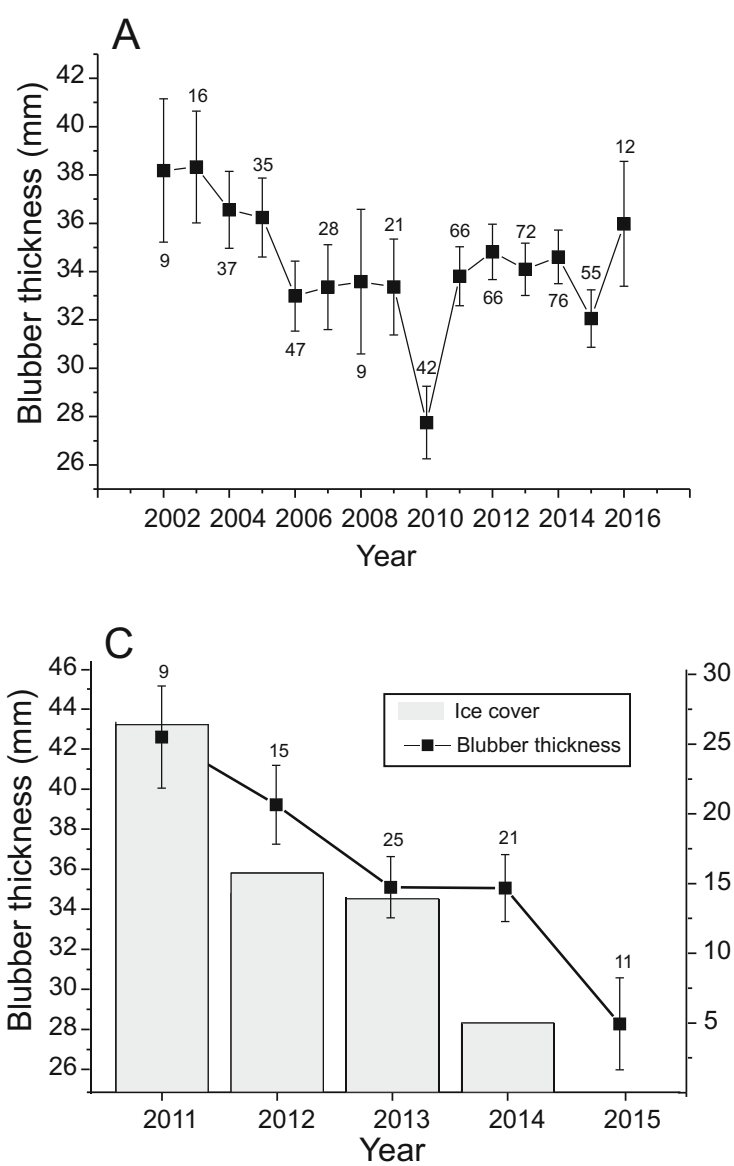

Fig. 3 Blubber thickness of gray seal pups (means \pm SE and sample sizes of model predicted values with other significant variables as covariates): a total data of pups in different years and $\mathbf{b}$ among different sea regions, $\mathbf{c}$ blubber thickness of hunted gray seal pups in the Gulf of Finland and days with permanent ice cover (in 2015 there was no ice) between 15 February

In Baltic Proper (the largest sample size for pups in the study), the mean weight of 5-6-year-old herring explained well the significant annual variation in blubber thickness during the whole study period $\left(r^{2}=0.55, F=13.6, d f=1,11\right.$, $p=0.004$; Table 4, Appendix Table 6). A declining trend in blubber thickness was found from $37.5 \mathrm{~mm}( \pm 2.30)$ in 2003 to $28.9 \mathrm{~mm}( \pm 1.53)$ in 2010 (slope $=-0.86, F=5.4, p=0.021$, $n=145$ ), which was also explained well by the declining herring weight (Fig. 3d, Appendix Table 6), whereas blubber thickness correlated negatively with herring catch size $(r=-0.77, p=0.026$, Appendix Table 7). There was a declining trend in the blubber thickness of pups also in the Bothnian Sea, from $43.8 \mathrm{~mm}( \pm 4.61)$ in 2003 to $25.4 \mathrm{~mm}( \pm 2.47)$ in 2010 (slope $=-1.25, F=5.0, p=0.029, n=66$ ), but no significant relationship with herring weight, herring catch size or ice conditions could be found. Data from Archipelago Sea were too small for a trend analysis. No significant trend in the blubber thickness of pups was found in the Bothnian Bay ( $p=0.467$ ) from 2011 to 2015 (data for earlier years were excluded due to small sample sizes).
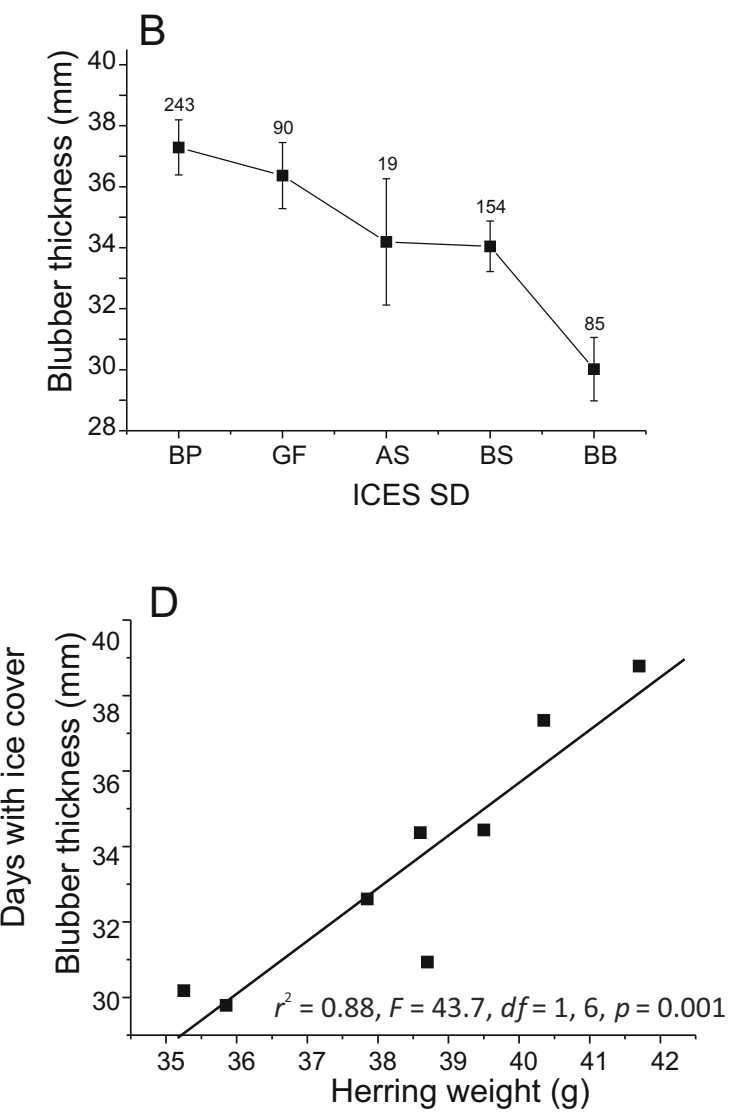

and 15 March in 2011-2015, and $\mathbf{d}$ blubber thickness of pups in Baltic Proper in 2003-2010 as a function of average weight of 5-6-year-old herring. $B P$ Baltic proper, $G F$ the Gulf of Finland, $A S$ Archipelago Sea, $B S$ the Bothnian Sea, $B B$ the Bothnian Bay

\section{Sub-adults and adults}

All tested variables significantly affected the blubber thickness of the pooled data of sub-adult gray seals (Table 5). The weight of 5-6-year-old herring best explained the annual variation in blubber thickness from 2004 to $2010\left(r^{2}=0.66, F=9.8, d f=1,5, p=0.026\right.$, Appendix Table 6), although no significant trend could be found in blubber thickness over time (Fig. 4a). There was a negative correlation between the herring catch size and the blubber thickness of sub-adults $(r=-0.88, p=0.009$, Appendix Table 7). Only month significantly affected the blubber thickness of hunted sub-adults (Table 5). Kruskal-Wallis analysis gave similar results for hunted sub-adults (month-blubber thickness: $\mathrm{K}-\mathrm{W}$ test statistic $=5.4, p<0.001)$. In Baltic Proper, there was an increasing trend in blubber thickness from $30.1 \mathrm{~mm}( \pm 2.49)$ in 2010 to $36.8 \mathrm{~mm}( \pm 2.04)$ in 2014 (slope $=2.02, F=6.7, p=0.012, n=76$ ) but in 2015 blubber thickness dropped to $30.1 \mathrm{~mm}( \pm 1.83)$. 
Table 5 Results of GLM for sub-adult and adult gray seals (2002-2015). The effects of all independent variables on the blubber thickness of gray seals were tested in the same analysis to get a single model (GLM)

\begin{tabular}{|c|c|c|c|c|c|c|}
\hline \multirow[t]{2}{*}{ Independent variable } & \multicolumn{3}{|c|}{ Sub-adults $(n=465)$} & \multicolumn{3}{|c|}{ Adults $(n=1100)$} \\
\hline & $F$ & $d f$ & $p$ & $F$ & $d f$ & $p$ \\
\hline \multicolumn{4}{|l|}{ Total data: } & \multicolumn{3}{|c|}{ Total data } \\
\hline Year & 1.90 & 13 & 0.028 & - & - & - \\
\hline Month & 7.61 & 8 & $<0.001$ & 42.1 & 8 & $<0.001$ \\
\hline Sea region & 2.72 & 4 & 0.029 & 5.8 & 4 & $<0.001$ \\
\hline Sex & 8.75 & 1 & 0.003 & 16.9 & 1 & $<0.001$ \\
\hline Cause of death & 31.86 & 1 & $<0.001$ & 143.7 & 1 & $<0.001$ \\
\hline Multiple $R$ & 0.56 & & & 0.57 & & \\
\hline Squared mulple $R$ & 0.31 & & & 0.32 & & \\
\hline \multicolumn{4}{|l|}{ Hunted (279) } & \multicolumn{3}{|c|}{$\begin{array}{l}\text { Hunted adult } \\
\text { females } \\
(487)\end{array}$} \\
\hline Year & - & - & - & 2.6 & 13 & 0.002 \\
\hline Month & 7.7 & 8 & $<0.001$ & 11.8 & 8 & $<0.001$ \\
\hline Sea region & - & - & - & 6.7 & 4 & $<0.001$ \\
\hline Sex & - & - & - & - & - & - \\
\hline Multiple $R$ & 0.43 & & & 0.58 & & \\
\hline Squared mulple $R$ & 0.19 & & & 0.34 & & \\
\hline \multicolumn{4}{|l|}{ Baltic Proper (201) } & \multicolumn{3}{|c|}{$\begin{array}{l}\text { Hunted adult } \\
\text { females } \\
\text { in BB (299) }\end{array}$} \\
\hline Year & 1.8 & 13 & 0.042 & 3.8 & 13 & $<0.001$ \\
\hline Month & - & - & - & 14.1 & 8 & $<0.001$ \\
\hline Sex & 12.2 & 1 & 0.001 & - & - & - \\
\hline Cause of death & 104.4 & 1 & $<0.001$ & - & - & - \\
\hline Multiple $R$ & 0.66 & & & 0.62 & & \\
\hline Squared mulple $R$ & 0.44 & & & 0.38 & & \\
\hline
\end{tabular}

$\mathrm{F}, d f$, and $p$ for each independent variable, and multiple $R$ and squared multiple $R$ of the model are given. Independent variables tested were as follows: year, month, sea region, sex, and cause of death (hunted vs by-caught). For sea regions, see Fig. 1

The weight of age $6+$ herring best explained the increase $\left(r^{2}=0.88, F=21.0, d f=1,3, p=0.019\right.$, Appendix Table 6). No significant trends were found in blubber thickness of sub-adults in other regions.

Blubber thickness of sub-adults and adults decreased from April to July and increased during the autumn (Fig. 4b). It was greatest in the Gulf of Finland $(37.5 \mathrm{~mm} \pm 1.88$ and $37.6 \mathrm{~mm} \pm 1.78$ for sub-adults and adults, respectively) and smallest in the Bothnian Bay $(31.7 \mathrm{~mm} \pm 1.20$ and $31.6 \mathrm{~mm} \pm 1.20)$. Females had more blubber than males, and hunted seals more than by-caught seals (Table 3).

According to GLM, blubber thickness of adult gray seals differed significantly between months, regions, sexes, and cause of death but not between years (Table 5). Kruskal-Wallis analysis gave similar results $(p<0.05)$ for all variables, except $\operatorname{sex}(p=0.323)$.

\section{Hunted adult seals}

Year, month, and region significantly affected the blubber thickness of hunted adult females (Table 5). Although there was annual variation, no significant trend was found in blubber thickness in the total data of hunted adult females. Females killed in the Bothnian Bay were the slimmest (BB: $44.3 \mathrm{~mm} \pm 1.15, n=299$, other regions: $49.2-49.7, n=188$ ), and in $\mathrm{BB}$, there was an increasing trend in blubber thickness from 2008 to 2015 (slope $=1.28, F=10.1, p=0.002$, $n=178$; Fig. 4c) which was best explained by the mean weight of 7-year-old herring (Fig. 4d, Appendix Table 6). There was also a significant increasing trend when we included only hunted females from spring (April-June) from BB in the analysis (slope $=1.68$, $F=17.9, p<0.001, n=145)$. Year did not affect 

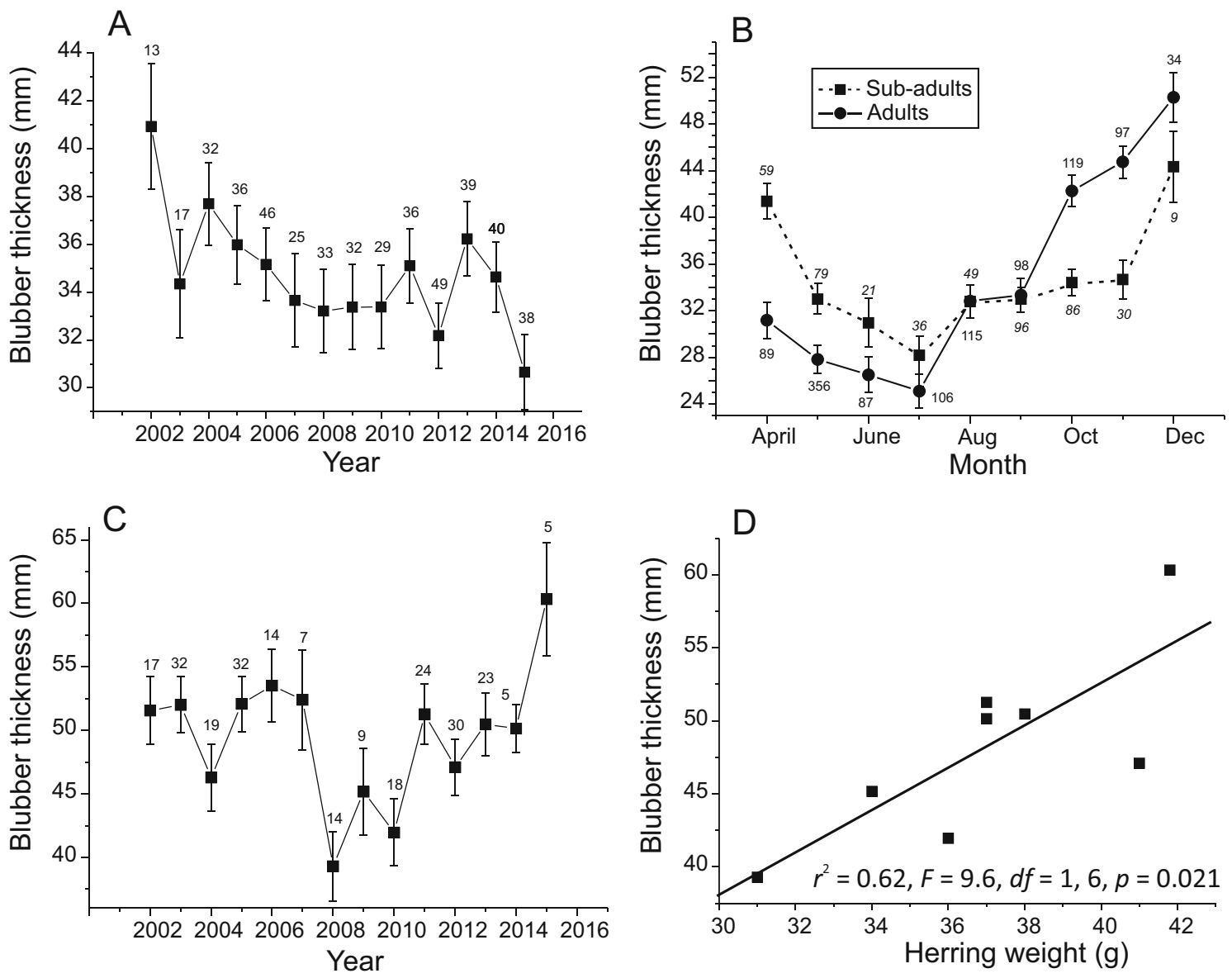

Fig. 4 Blubber thickness of sub-adult and adult gray seals (means \pm SE and sample sizes of model predicted values with other significant variables as covariates): a blubber thickness of the total data of sub-adults in different years, $\mathbf{b}$ blubber thickness of sub-adult and adult gray seals in

different months, $\mathbf{c}$ blubber thickness of hunted adult female gray seals in different years in the Bothnian Bay, and $\mathbf{d}$ blubber thickness of hunted adult females in the Bothnian Bay in 2008-2015 as a function of average weight of 7-year-old herring

blubber thickness in the Bothnian Sea $(p=0.747)$. Sample sizes from other areas were too small for the analysis.

Only month $(F=20.8, d f=1,8, p<0.001)$ and region $(F=2.9, d f=1,4, p=0.022)$ significantly affected the blubber thickness of hunted adult males. Blubber thickness of hunted adult males was lowest in the Bothnian Bay (mean $43.1 \mathrm{~mm} \pm 1.31, n=101$ ) and highest in the Gulf of Finland (56.2 $\mathrm{mm} \pm 4.04, n=9)$.

\section{Discussion}

Blubber thickness of the pooled sample, and that of pups, subadults, and hunted adult females varied between years. There was a declining trend in the blubber thickness of the total data and in the age group pups before 2010, whereas the blubber thickness of pups (except in the Gulf of Finland), sub-adults in Baltic Proper and hunted adult females in the Bothnian Bay increased in recent years. Among the variables tested here, the weight of herring best explained the inter-annual variation and trends in the blubber thickness. The exception was the blubber thickness of pups in GF, which declined in recent years simultaneously with decreasing number of days with permanent ice cover in late winter.

\section{Herring in the diet of Baltic gray seals}

Results of the present study point to the conclusion that herring is an important food source for gray seals, and herring quality (but not the quantity) is crucial for the nutritional status of seals. When herring weight is low, seals must use more energy on foraging than herring is fatty. The results also point at gray seals being food limited, since they respond to annual changes in herring quality. Earlier studies have shown that herring is the most important prey fish for Baltic gray seals (Lundström et al. 2007, 2010; Stenman 2009; Kauhala et al. 2011; Gårdmark et al. 2012). Gray seal diet, determined from hard parts of prey in digestive tracks, was dominated by the herring (both by numbers and biomass) in the early 2000 s 
Table 6 The interactions (regression analysis) between the mean weight of herring or ice conditions (independent variables) and the blubber thickness of gray seals. Results with $p<0.10$ and $F>4.0$ are included. All interactions are positive. Data for 2002 (for sub-adults also 2003) were excluded due to small sample sizes. Ice conditions $=$ the number of days with permanent ice cover between 15 February and 15 March $. \mathrm{BP}=$ Baltic proper, $\mathrm{GF}=$ the Gulf of Finland, $\mathrm{BS}=$ the Bothnian Sea, $\mathrm{BB}=$ the Bothnian Bay. Subscript in the right column: $\mathrm{S}=$ southern regions $(\mathrm{BP}+\mathrm{AS}+\mathrm{GF})$. Pups: < one year old, sub-adults: $1-3$ years old, adults: $>$ three years old

\begin{tabular}{|c|c|c|c|c|c|c|c|}
\hline Data set & Time period & $r^{2}$ & $t$ & $F$ & $d f$ & $P$ & Independent variable \\
\hline Total data & 2003-2015 & 0.36 & 2.5 & 6.1 & 1,11 & 0.031 & 5-6-year-old herring ${ }_{(\mathrm{S})}$ \\
\hline Total data & 2003-2015 & 0.36 & 2.5 & 6.2 & 1,11 & 0.030 & age $6+$ herring $_{(\mathrm{S})}$ \\
\hline Total data & 2003-2010 & 0.79 & 4.8 & 23.0 & 1,6 & 0.003 & 5-6-year-old herring $(\mathrm{S})$ \\
\hline Total data & 2003-2010 & 0.41 & 2.0 & 4.2 & 1,6 & 0.087 & 5-6-year-old herring $(\mathrm{S}+\mathrm{BS})$ \\
\hline Total data & 2003-2010 & 0.59 & 2.9 & 8.6 & 1,6 & 0.026 & age $6+$ herring $_{(\mathrm{S})}$ \\
\hline Total data & 2003-2010 & 0.73 & 4.0 & 16.2 & 1,6 & 0.007 & age $6+$ herring $_{(\mathrm{S}+\mathrm{BS})}$ \\
\hline Pups, total & 2003-2015 & 0.30 & 2.2 & 4.8 & 1,11 & 0.051 & 5-6-year-old herring ${ }_{(\mathrm{S})}$ \\
\hline Pups total & 2003-2010 & 0.65 & 3.3 & 11.0 & 1,6 & 0.016 & 5-6-year-old herring $(\mathrm{S})$ \\
\hline Pups, spring, GF & $2011-2015$ & 0.83 & 3.9 & 14.8 & 1,3 & 0.031 & Ice conditions \\
\hline Hunted pups, GF & 2011-2015 & 0.85 & 4.1 & 16.8 & 1,3 & 0.026 & Ice conditions \\
\hline Pups, excl. GF & 2010-2016 & 0.78 & 3.7 & 14.0 & 1,4 & 0.020 & 5-6-year-old herring ${ }_{(\mathrm{S})}$ \\
\hline Pups, excl. GF & $2010-2016$ & 0.60 & 2.5 & 6.1 & 1,4 & 0.069 & age $6+$ herring $_{(\mathrm{S})}$ \\
\hline Pups, BP & 2003-2015 & 0.54 & 3.6 & 12.8 & 1,11 & 0.004 & 5-6-year-old herring $(\mathrm{S})$ \\
\hline Pups, BP & $2003-2015$ & 0.31 & 2.2 & 4.9 & 1,11 & 0.049 & age $6+$ herring $_{(\mathrm{S})}$ \\
\hline Pups, BP & $2003-2010$ & 0.88 & 6.5 & 42.2 & 1,6 & 0.001 & 5-6-year-old herring $(\mathrm{S})$ \\
\hline Sub-adults, total & 2004-2010 & 0.66 & 3.1 & 9.8 & 1,5 & 0.026 & 5-6-year-old herring $(\mathrm{S})$ \\
\hline Sub-adults, total & 2004-2010 & 0.58 & 2.6 & 6.8 & 1,5 & 0.047 & 5-6-year-old herring $(\mathrm{S}+\mathrm{BS})$ \\
\hline Sub-adults, total & 2004-2010 & 0.63 & 2.9 & 8.4 & 1,5 & 0.034 & age $6+$ herring $_{(\mathrm{S}+\mathrm{BS})}$ \\
\hline Sub-adults, BP & 2004-2010 & 0.49 & 2.2 & 4.7 & 1,5 & 0.082 & 5-6-year-old herring $(\mathrm{S})$ \\
\hline Sub-adults, BP & $2010-2014$ & 0.66 & 2.4 & 5.7 & 1,3 & 0.096 & 5-6-year-old herring $(\mathrm{S})$ \\
\hline Sub-adults, BP & 2010-2014 & 0.88 & 4.6 & 21.0 & 1,3 & 0.019 & age $6+$ herring $_{(\mathrm{S})}$ \\
\hline Adult females, BB & $2008-2015$ & 0.44 & 2.2 & 4.7 & 1,6 & 0.073 & age $6+$ herring $_{(\mathrm{BB})}$ \\
\hline Adult females, BB & 2008-2015 & 0.62 & 3.1 & 9.6 & 1,6 & 0.021 & 7-year-old herring $(\mathrm{BB})$ \\
\hline
\end{tabular}

throughout the Baltic Sea (Lundström et al. 2007). Although geographic region and age group affected the diet of Baltic gray seals, herring was the most important prey fish in all areas and age groups, occurring in $85 \%$ of gray seal digestive tracks (Lundström et al. 2010). The proportion of herring in the diet of gray seals in the Bothnian Bay was 83\% (Stenman 2009). According to Garrdmark et al. (2012), the mean age of herring in gray seal diet was 6.3 years, although the mean age of individuals in the population was only 3.3 years, indicating that gray seals pick the older and heavier herring. The results of the present study suggest that pups probably prey on younger herring than older seals, but even pups prey mainly on 56-year-old herring, because the weight of these best explained the variation in the blubber thickness of pups.

\section{Importance of herring quality on Baltic gray seals}

In the Finnish samples of gray seals from 2001 to $2007,80 \%$ of identified prey fish in the stomachs were herring, and herring was especially frequent in the stomachs of female gray seals in the northernmost parts of the Baltic Sea (Kauhala et al.
2011). The increasing herring weight in recent years thus likely caused the increase in the blubber thickness of adult females in the Bothnian Bay. Furthermore, an earlier study (Kauhala et al. 2016) showed that the birth rate (\% mature females giving birth each year) of gray seals increased during recent years with increasing herring weight. Blubber thickness of hunted adult females also partly explained the variation in the birth rate of gray seal females (birth rate from Kauhala et al. 2016: Table 2; $r^{2}=0.53, F=8.9, d f=1,6, p=0.024$ ) in recent years. Nutritional status (or body mass) of female seals may thus have an impact on reproduction (age at sexual maturity, ovulation rate, implantation of embryos, and maintenance of pregnancy) of seal females (e.g., Boyd 1984; Boyd et al. 1999; Harwood et al. 2000; Bowen et al. 2006, 2015).

Nutritional status of pups affects their first year survival, especially in male pups (Baker 1984; Hall et al. 2001, 2002). One reason may be thermal stress of small pups in cold water in winter (Harding et al. 2005). Nutritional status of pups may also affect the age when they reach sexual maturity, i.e., reproduction later in their lives (Boyd et al. 1999). Thus, we can expect 
Table 7 Correlations between herring catch size and blubber thickness of gray seals. Results with $p<0.10$ are included. $\mathrm{BP}=$ Baltic proper, $\mathrm{GF}=$ the Gulf of Finland, $\mathrm{BS}=$ the Bothnian Sea, $\mathrm{S}=$ southern regions $(\mathrm{BP}+\mathrm{AS}+\mathrm{GF})$. Pups: < one year old, sub-adults: $1-3$ years old

\begin{tabular}{|c|c|c|c|c|}
\hline Data set & Time period & $r$ & $p$ & Age group of herring \\
\hline Total data & $2003-2015$ & -0.57 & 0.043 & 5-6-year-old herring $(\mathrm{S})$ \\
\hline Total data & $2003-2015$ & -0.70 & 0.008 & age $6+$ herring $_{(\mathrm{S})}$ \\
\hline Total data & 2003-2010 & -0.70 & 0.053 & 5-6-year-old herring $(\mathrm{S})$ \\
\hline Total data & 2003-2010 & -0.86 & 0.006 & age $6+$ herring $_{(\mathrm{S})}$ \\
\hline Total data & 2003-2010 & -0.77 & 0.025 & age $6+$ herring $_{(\mathrm{S}+\mathrm{BS})}$ \\
\hline Pups, total & 2003-2015 & -0.49 & 0.092 & 5-6-year-old herring $(\mathrm{S})$ \\
\hline Pups, total & 2003-2015 & -0.56 & 0.049 & age $6+$ herring $_{(\mathrm{S})}$ \\
\hline Pups, BP & 2003-2015 & -0.51 & 0.074 & 5-6-year-old herring $(\mathrm{S})$ \\
\hline Pups, BP & 2003-2015 & -0.53 & 0.064 & age $6+$ herring $_{(\mathrm{S})}$ \\
\hline Pups, BP & 2003-2010 & -0.77 & 0.026 & 5-6-year-old herring $(\mathrm{S})$ \\
\hline Sub-adults, total & 2004-2010 & -0.72 & 0.068 & 5-6-year-old herring $(\mathrm{S})$ \\
\hline Sub-adults, total & 2004-2010 & -0.79 & 0.036 & age $6+$ herring $_{(\mathrm{S})}$ \\
\hline Sub-adults, total & 2004-2010 & -0.88 & 0.009 & age $6+$ herring $_{(\mathrm{S}+\mathrm{BS})}$ \\
\hline
\end{tabular}

consequences for gray seal population dynamics due to fluctuations in herring weight.

\section{Factors affecting herring weight}

There was a negative correlation between herring weight and herring catch size, i.e., herring weight decreased with the increasing herring population density, indicating a possibility of intra-specific competition for resources in the herring population, which was indeed observed, e.g., in the Bothnian Sea by Östman et al. (2014). Furthermore, the sprat (Sprattus sprattus) is the main food (zooplankton) competitor for herring and its numbers affect herring growth and condition (Casini et al. 2006, 2010). There was indeed a negative correlation between herring weight and the catch size of the sprat (an estimate of sprat population numbers; ICES 2016) in the southern sea regions (BP, AS, GF; $r=-0.70, p=0.006$ for $5-$ 6 -year-old herring and $r=-0.63, p=0.016$ for $6+$ years old herring) in 2002-2015, suggesting possible inter-specific competition between these species. The sprat, on the other hand, is the main prey of the cod (Gadus morhua), and sprat population is thus affected by cod numbers (Casini et al. 2008). The factors affecting the cod population (such as salinity and volume of oxygenated water; Casini et al. 2006) in the Baltic Sea may thus be partly responsible for the changes in the sprat population, herring weight, and gray seal nutritional status.

Climate warming may increase the recruitment of herring, as, e.g., in the Bothnian Sea, abundant year classes of herring have appeared in warm years (ICES 2017). Increasing density along with possibly reducing salinity (e.g., HELCOM 2013) may, however, also increase intraspecific competition, which can lead to decreased growth rate and condition of herring. At present, herring is indeed abundant but small sized in the Gulf of Riga compared with herring in the Bothnian Sea (ICES 2017). The Gulf of Riga is a warmer area where salinity is corresponding to that of the Bothnian Sea.

\section{Impact of climate change on gray seal pups}

Ice cover in the breeding season and the blubber thickness of pups in the Gulf of Finland were positively linked in recent years. When there is little ice, many gray seal females gather on small islets and give birth on land. Pups born on land in areas, where females normally give birth on drift ice, have been found to be lighter at the time of weaning than pups born on ice (Jüssi et al. 2008). One reason behind this phenomenon may be the males which gather on the islets during the nursing period when females come into estrus. Males thus disturb nursing, and pups may suffer malnutrition during their first weeks of life. Moreover, the higher density of seals on the islets may contribute to the spread of infections between seals, females may have stress because they do not have easy access to water and, where many seals gather, there is also more disturbance by, e.g., white tailed eagles (Haliaetus albicilla) (Jüssi et al. 2008). The connection between ice cover and the blubber thickness of pups was, however, found only in the Gulf of Finland. Gulf of Finland is the smallest and the most enclosed of the studied sea regions. It is also the region forecasted to be most affected by warm winters with destruction of ice cover (Sundqvist et al. 2012). In the Gulf of Finland, ice availability thus becomes a limiting factor before the trend can be seen in the other sea regions.

\section{Nutritional status of gray seals as an indicator of the Baltic Sea environment}

Decline in the nutritional status of pups may be the first warning signal of environmental changes, especially changes in the food web in the Baltic Sea ecosystem or changes in the ice cover, because pups are usually the first to suffer when environmental conditions become poor (Lonergan et al. 2011).

The blubber thickness of sub-adults is used as a seal health indicator by HELCOM (Baltic Marine Environment Protection Commission), because it is supposed to reflect the environmental status and changes in the environment of the Baltic Sea (Harding et al. 2015). The nutritional status of subadults in Baltic Proper increased with increasing weight of older herring in recent years, but dropped suddenly in 2015 for unknown reason. This may be alarming, if the decline continues in forthcoming years. It is therefore important to monitor the nutritional status of seals and to reveal the factors affecting it, such as food quality, and thus obtain information of the possible changes in the Baltic Sea ecosystem. 


\section{Conclusions}

Herring is an important food source for Baltic gray seals, and its quality is crucial for the nutritional status of the seals. The results suggest that gray seals are food limited, since they respond to temporal changes in herring quality. Ice cover is decreasing with warming climate which has an effect on the nutritional status of seal pups. Climate change may also affect the marine food web (Burke et al. 2008) and thus herring quality and the nutritional status of gray seals. Nutritional status of gray seals may thus be a good indicator of changes in the Baltic Sea ecosystem, including marine food web and ice conditions.

We cannot, however, rule out the possibility of other factors affecting the blubber thickness of seals, for instance, parasites, diseases, environmental contaminants or the date of birth of pups, and the nutritional status of females which may affect the nutritional status of pups (Pomeroy et al. 1999; Bowen et al. 2006). Furthermore, seal population density may affect intra-specific competition for resources and thus the nutritional status, mortality rate of pups and reproductive rate of adult seals (e.g., Hammill and Gosselin 1995; Boyd et al. 1999).

Acknowledgements We are grateful to J. Vainio from the Finnish Meteorological Institute for providing data of the ice conditions in the Baltic Sea. We wish to thank all hunters and fishermen who sent us samples of seals, and C. Moraeus and P. Timonen who helped us in the laboratory.

\section{Appendix}

\section{References}

Bäcklin BM, Moraeus C, Roos A, Eklöf E, Lind Y (2011) Health and age and sex distributions of Baltic grey seals (Halichoerus grypus) collected from bycatch and hunt in the Gulf of Bothnia. ICES J Mar Sci 68:183-188

Baker JR (1984) Mortality and morbidity in grey seal pups (Halichoerus grypus). Studies on its causes, effects of environment, the nature and sources of infectious agents and the immunological status of pups. J Zool 203:23-48

Bowen WD, Iverson SJ, McMillan JI, Boness DJ (2006) Reproductive performance in grey seals: age-related improvement and senescence in a capital breeder. J Anim Ecol 75:1340-1351

Bowen WD, Heyer CE, McMillan JI, Iverson SI (2015) Offspring size at weaning affects survival to recruitment and reproductive performance of primiparous gray seals. Ecol Evol 5:1412-1424

Boyd IL (1984) The relationship between body condition and the timing of implantation in pregnant Grey seals (Halichoerus grypus). J Zool 203:113-123

Boyd IL, Lockyer C, Marsh HD (1999) Reproduction in marine mammals. In: Reynolds JE, Rommel SA (eds) Biology of marine mammals. Smithsonian Institution Press, Washington
Burke KA, Gulland FMD, O’Hara TM (2008) Effects of climate change on arctic marine mammal health. Ecol Appl 18:S126-S134

Casini M, Cardinale M, Hjelm J (2006) Inter-annual variation in herring, Clupea harengus, and sprat, Sprattus sprattus, condition in the central Baltic Sea: what gives the tune? Oikos 112:638-650

Casini M, Lövgren J, Hjelm J, Cardinale M, Molinero JC, Kornilovs G (2008) Multi-level trophic cascades in a heavily exploited open marine ecosystem. Proc R Soc B Biol Sci 275:1793-1801

Casini M, Bartolino V, Molinero JC, Kornilovs G (2010) Linking fisheries, trophic interactions and climate: threshold dynamics drive herring Clupea harengus growth in the central Baltic Sea. Mar Ecol Prog Ser 413:241-252

Durbin J, Watson GS (1951) Testing for serial correlation in least squares regression, II. Biometrika 38:159-179

Gårdmark A, Östman Ö, Nielsen A, Lundström K, Karlsson O, Pönni J, Aho T (2012) Does predation by grey seals (Halichoerus grypus) affect Bothnian Sea herring stock estimates? ICES J Mar Sci 69: 1448-1456

Hall AJ, McConnell BJ, Barker RJ (2001) Factors affecting first-year survival in grey seals and their implications for life history strategy. J Anim Ecol 70:138-149

Hall AJ, McConnell BJ, Barker RJ (2002) The effect of total immunoglobulin levels, mass and condition on the first-year survival of Grey seal pups. Funct Ecol 16:462-474

Hammill MO, Gosselin JF (1995) Grey seal (Halichoerus grypus) from the Northwest Atlantic: female reproductive rates, age at first birth, and age of maturity in males. Can J Fish Aquat Sci 52:2757-2761

Harding KC, Fujiwara M, Axberg Y, Härkönen T (2005) Mass-dependent energetics and survival in harbour seal pups. Funct Ecol 19:129-135

Harding KC, Bäcklin BM, Moraeus C, Kauhala K, Siebert U, Härkönen $\mathrm{T}$ (2015) Nutritional status of Baltic seals. HELCOM core indicator report. Online: http://www.helcom.fi/Core\%20Indicators/ Nutritional $\% 20$ status $\% 20$ of $\% 20$ marine $\% 20$ mammals HELCOM\%20core\%20indicator\%20report\%202015_web\% 20version.pdf

Harwood LA, Smith TG, Melling H (2000) Variation in reproduction and body condition of the ringed seal (Phoca hispida) in western Prince Albert sound, NT, Canada, as assessed through a harvest-based sampling program. Arctic 53:422-431

HELCOM (2013) Climate change in the Baltic Sea area HELCOM thematic assessment in 2013. Baltic Sea environment proceedings no. 137. Helsinki Commission, Baltic Marine Environment Protection Commission. pp. 66

ICES (2016) Report of the Baltic fisheries assessment working group (WGBFAS), 12-19 April 2016, ICES HQ, Copenhagen, Denmark. ICES CM 2016/ACOM:11. 594 pp. Online: http://www.ices.dk/ sites/pub/Publication\%20Reports/Expert\%20Group\%20Report/ acom/2016/WGBFAS/01\%20WGBFAS\%20Report\%202016.pdf

ICES (2017) Report of the Baltic fisheries assessment working group (WGBFAS). 19-26 April, Copenhagen, Denmark. ICES CM 2017/ACOM:11. Pp. 787

Jüssi M, Härkönen T, Helle E, Jüssi I (2008) Decreasing ice coverage will reduce the breeding success of Baltic grey seal (Halichoerus grypus) females. Ambio 37:80-85

Kauhala K, Kunnasranta M, Valtonen M (2011) Hallien ravinto Suomen merialueella 2001-2007 - alustava selvitys [diet of grey seals in Finland in 2001-2007 - a preliminary study]. Suomen Riista 57: 73-83 [In Finnish with English summary]

Kauhala K, Ahola MP, Isomursu M, Raitaniemi J (2016) The impact of food resources, reproductive rate and hunting pressure on the Baltic grey seal population in the Finnish sea area. Ann Zool Fenn 53:296309

Keinänen M, Uddström A, Mikkonen J, Casini M, Pönni J, Myllylä T, Aro E, Vuorinen PJ (2012) The thiamine deficiency syndrome M74, a reproductive disorder of Atlantic salmon (Salmo Salar) feeding in 
the Baltic Sea, is related to the fat and thiamine content of prey fish. ICES J Mar Sci 69:516-528

Kjellqvist SA, Haug T, Øritsland (1995) Trends in age-composition, growth and reproductive parameters of Barents Sea harp seals, Phoca groenlandica. ICES J Mar Sci 52:197-208

Kuiken T, Bennett PM, Colin RA, Kirkwood JK, Baker JR, Lockyer CH, Walton MJ, Sheldrick MC (1994) PCBs, cause of death and body condition in harbor porpoises (Phocoena phocoena) from British waters. Aquat Toxicol 28:13-28

Lonergan M, Duck CD, Thompson D, Moss S, McConnell B (2011) British grey seal (Halichoerus grypus) abundance in 2008: an assessment based on aerial counts and satellite telemetry. ICES J Mar Sci 68:2201-2209

Lundström K, Hjerne O, Alexandersson K, Karlsson O (2007) Estimation of grey seal (Halichoerus grypus) diet composition in the Baltic Sea. Nammco Sci Publ 6:177-196

Lundström K, Hjerne O, Lunneryd SG, Karlsson O (2010) Understanding the diet composition of marine mammals: grey seals (Halichoerus grypus) in the Baltic Sea. ICES J Mar Sci 67:12301239

Mansfield AW (1991) Accuracy of age determination in the grey seal Halichoerus grypus of eastern Canada. Mar Mamm Sci 7:44-49
Östman Ö, Karlsson O, Pönni J, Kaljuste O, Aho T, Gårdmark A (2014) Relative contributions of evolutionary and ecological dynamics to body size and life-history changes of herring (Clupea harengus) in the Bothnian Sea. Evol Ecol Res 16:417-433

Pomeroy PP, Fedak MA, Rothery P, Anderson S (1999) Consequences of maternal size for reproductive expenditure and pupping success of grey seals at north Rona, Scotland. J Anim Ecol 68:235-253

Slotte A (1999) Differential utilization of energy during wintering and spawning migration in Norwegian spring-spawning herring. J Fish Biol 54:338-355

Stenman O (2009) Hallien kalaravinnosta Perämeren kevätjäillä [fish diet of grey seals in the Bothnian Bay in spring]. Suomen Kalastuslehti 3:15-17 [In Finnish]

Sundqvist L, Harkonen T, Svensson CJ, Harding KC (2012) Linking climate trends to population dynamics in the Baltic ringed seal: impacts of historical and future winter temperatures. Ambio 41: 865-871

Vuorinen PJ, Parmanne R, Vartiainen T, Keinänen M, Kiviranta H, Kotovuori O, Halling F (2002) PCDD, PCDF, PCB and thiamine in Baltic herring (Clupea Harengus L.) and sprat [Sprattus Sprattus (L.)] as a background to the M74 syndrome of Baltic salmon (Salmo Salar L.) ICES J Mar Sci 59:480-496 